\title{
Pengaruh Penerapan SVLK, FSC, PEFC Terhadap Daya Saing Industri Kertas di Jawa Tengah
}

\author{
Agus Purwanto ${ }^{1}$, Mirza Prameswari ${ }^{2}$, Fredson Kotamena ${ }^{3}$, Masduki Asbari ${ }^{4}$, \\ Priyono Budi Santoso ${ }^{5}$, Mohamad Ramdan ${ }^{6}$, Andi Sulistiadi ${ }^{7}$, Laksmi Mayesti Wijayanti ${ }^{8}$, \\ Choi Chi Hyun ${ }^{9}$, Otto Berman Sihite ${ }^{10}$, Rudy Pramono ${ }^{11}$ \\ $1,2,3,3,4,5,6,7,8,9,10,11$ Universitas Pelita Harapan, Tangerang, Indonesia \\ Email : agozpor@gmail.com
}

\begin{abstract}
The purpose of this study was to determine the effect of the SVLK Timber Legality and Verification System, FSC Chain of Custody, PEFC Sustainable Forest Management for wood and wood-based products on the competitiveness of the wood industry in Central Java. This research was conducted in several companies that process wood or use wood as the main material in Central Java with a total of 300 respondents. The respondents of this study are wood industry employees as top management, managers and staff who have been implementing SVLK, FSC, PEFC for at least 2 years. The background of this study is due to the lack of PEFC, FSC and SVLK research on the wood industry in Indonesia's Central Java province. Data collection was carried out by distributing electronic questionnaires online during January 2020 and analyzing data processing using Structural Equation Model (SEM) and Linear Structural Model (LISREL) software version 8.70. The analysis shows that the application of SVLK, FSC Chain of Custody, PEFC Sustainable Forest Management significantly and positively affects the company's competitiveness such as increased customer satisfaction, increased sales and decreased customer complaints.
\end{abstract}

Keywords : Competitiveness, SVLK, FSC,PEFC

Abstrak

Tujuan dari penelitian ini adalah untuk mengetahui pengaruh Sistem Verifikasi dan Legalitas Kertas SVLK, FSC Chain of Custody, PEFC Sustainable Forest Management untuk kertas dan produk berbasis kertas terhadap daya saing industri kertas di Jawa Tengah. Penelitian ini dilakukan di beberapa perusahaan yang mengolah kertas atau menggunakan kertas sebagai bahan utama di Jawa Tengah dengan jumlah responden sebanyak 300 orang. Responden penelitian ini adalah karyawan industri kertas sebagai manajemen puncak, manajer dan staf yang memiliki telah menerapkan SVLK, FSC, PEFC selama minimal 2 tahun. Latar belakang penelitian ini adalah karena kurangnya penelitian PEFC, FSC dan SVLK pada industri kertas di provinsi Jawa Tengah Indonesia. Pengumpulan data dilakukan dengan mendistribusikan kuesioner elektronik secara online selama bulan Januari 2020 dan analisis pemrosesan data menggunakan Structural Equation Model (SEM) dan software Linear Structural Model (LISREL) versi 8.70. Hasil analisis menunjukkan bahwa penerapan SVLK, FSC Chain of Custody, PEFC Sustainable Forest Management mempengaruhi daya saing perusahaan secara signifikan dan positif seperti peningkatan kepuasan pelanggan, peningkatan penjualan dan penurunnan keluhan pelanggan.

Kata Kunci : Daya Saing, SVLK, FSC,PEFC

(C) 2020 Jurnal Riset Inspirasi Manajemen dan Kewirausahaan

\section{PENDAHULUAN}

Banyak usaha ekonomi produktif di desa Luas hutan mencakup lebih dari 30\% permukaan tanah Bumi, menurut World Wildlife Fund. Daerah hutan ini dapat menyediakan makanan, obat-obatan dan bahan bakar untuk lebih dari satu miliar orang. Indonesia memiliki tanah seluas 187,7 juta ha, terdiri dari hutan seluas 93,9 juta ha. Area lahan tertutup kawasan hutan terdiri dari: 85,85 juta ha $(45,7 \%)$ masih berhutan dan 34,54 juta ha $(18,4 \%)$ adalah lahan tidak berhutan (non-hutan).
Deforestasi Indonesia pada 2016-2017 adalah 0,48 juta ha (di dalam dan di luar kawasan hutan), yang merupakan deforestasi besar seluas 0,66 juta ha dikurangi dengan reboisasi 0,18 juta ha. Tingkat deforestasi untuk periode 2011-2017 adalah hasil dari perhitungan deforestasi bersih yang sudah mempertimbangkan kegiatan reboisasi. Sedangkan perhitungan pada periode sebelumnya masih menggunakan deforestasi bruto. Pada periode 20142015, 30\% deforestasi terjadi di kawasan kebakaran hutan dan lahan (Dephut, 2019). 
Tujuan dari pemantauan sumber daya hutan adalah untuk mengurangi deforestasi yang tidak direncanakan, memulihkan dan merehabilitasi hutan terdegradasi, pengelolaan hutan berkelanjutan, dan mengevaluasi fungsi penyerapan karbon oleh hutan, lahan berhutan dan pohon di luar hutan untuk memoderasi iklim global (Fujita, 2010). Melindungi hutan tropis menjadi semakin mendesak karena penurunan wilayah hutan sebesar $6 \%$ dan 17\% emisi karbon dioksida global (Baccini et al., 2012). Sangat diperlukan cara-cara untuk mengurangi kehilangan hutan dan mempertahankan cadangan oksigen (Brown, 2013; Sills, et al., 2014; Lee et al., 2018). Sebagian besar hutan menjadi deforestasi dan degradasi hutan yang tinggi (Sloan dan Sayer, 2015). Deforestasi berkontribusi besar terhadap peningkatan emisi gas rumah kaca global dan menghasilkan perubahan iklim (Harris et al., 2012). Banyak orang yang tinggal di hutan atau dekat hutan ini sangat bergantung pada sumber daya hutan dan mata pencaharian mereka terancam oleh deforestasi (Sunderlin et al., 2005). Newsom \& Hewitt (2005) meneliti dan menemukan bahwa $91 \%$ perusahaan bersertifikat diharuskan meningkatkan pelatihan pekerjanya, $82 \%$ meningkatkan keselamatan, dan sebanyak 64\% meningkatkan upah pekerja. Hirschberger Research (2005) sebanyak 183 dari 12 perusahaan hutan Rusia yang disertifikasi dengan luas total lebih dari 3,5 juta ha menemukan bahwa hasil sertifikasi hutan memperkuat hak kerja bagi pekerja perusahaan hutan. Maria Tysiachniouk (2005) meneliti sebagian besar perusahaan regional bersertifikat hutan karena perlindungan pekerja meningkat dan penundaan gaji menurun. Pekerja memahami bahwa sertifikasi dapat digunakan sebagai alat perlindungan sosial.

Ada banyak perusahaan yang memiliki sertifikat pengelolaan hutan pada tahun 2019 perusahaan di Indonesia yang telah bersertifikat sebanyak 580 (FSC.org, 2019). Banyak perusahaan yang bersertifikat hutan pada 2019, tujuan utama penerapan FSC, PEFC dan SLLK adalah untuk memenuhi peraturan pemerintah dan juga permintaan dari pelanggan, ada beberapa tujuan yang ingin dicapai yaitu meningkatkan daya saingseperti pelanggan indeks kepuasan, meningkatkan penjualan, meningkatkan produktivitas dan keselamatan dan kepuasan karyawan. Tujuan dari penelitian ini adalah untuk mengetahui pengaruh pengelolaan hutan FSC Chain of Custody, PEFC Sustainable Forest Management dan SVLK di industri kertas dan produk berbasis kertas terhadap daya saingi ndustri kertas di Jawa Tengah. Tujuan dari penelitian ini adalah untuk mengetahui pengaruh penerapan FSC, FSC dan SVLK.

\section{KAJIAN LITERATUR}

\section{Sistem Verifikasi Legalitas Kertas atau SVLK}

Sistem Verifikasi Legalitas Kertas atau SVLK berfungsi untuk memastikan produk kertas dan bahan bakunya diperoleh atau berasal dari sumber yang asal-usulnya dan pengelolaannya memenuhi aspek legalitas. Kertas disebut legal bila asal-usul kertas, izin penebangan, sistem dan prosedur penebangan, pengangkutan, pengolahan, dan perdagangan atau pemindahtanganannya dapat dibuktikan memenuhi semua persyaratan legal yang berlaku. SVLK disusun bersama oleh sejumlah pihak (parapihak). SVLK memuat standar, kriteria, indikator, verifier, metode verifikasi, dan norma penilaian yang disepakati para pihak( Dephut.go.id,2020).Pemerintah RI menerapkan SVLK untuk memastikan agar semua produk kertas yang beredar dan diperdagangkan di Indonesia memiliki status legalitas yang meyakinkan. Dengan SVLK, konsumen di luar negeri pun tak perlu lagi meragukan legalitas kertas yang berasal dari Indonesia. Dengan SVLK, para petani dari hutan rakyat dan masyarakat adat dapat menaikkan posisi tawar dan tak perlu risau hasil kertas nya diragukan keabsahannya ketika mengangkut kertas untuk dijual. Para produsen mebel yakin akan legalitas sumber bahan baku kertas nya sehingga lebih mudah meyakinkan para pembelinya di luar negeri. Indonesia memberlakukan langkah bertahap dalam penerapan SVLK. Ini sebagai langkah awal yang harus menunjukkan sertifikat legalitas sebelum menuju ke sertifikat pengelolaan hutan lestari (sustainability). ( Dephut.go.id, 2020). Pemberlakuan SVLK itu sendiri adalah untuk memberikan kepastian legalitas produk kertas Indonesia pada pasar global. Upaya ini diharapkan dapat meningkatkan daya saing produk perkertas an Indonesia, mengurangi praktek illegal logging dan perdagangan illegal. Lebih dari itu SVLK juga menyiratkan komitmen dalam upaya serius dan konsisten memperbaiki tata kelola kepemerintahan kehutanan Indonesia. SVLK memiliki prinsipprinsip perbaikan tata kelola lebih baik (governance), keterwakilan para pihak dalam pengembangan sistem maupun pemantauan (representativeness) serta transparansi (transparent) yaitu sistem terbuka untuk diawasi oleh semua pihak. SVLK merupakan upaya soft approach yaitu perbaikan tata kelola pemerintahan atas maraknya penebangan dan perdagangan kertas liar. SVLK merupakan pendekatan yang melengkapi upaya penindakan hukum (hard approach) yang lebih dulu dilakukan Pemerintah. Melalui pendekatan soft approach perbaikan atas tata usaha dan administrasi perkertas an diperbaiki melalui sistem yang dapat dipantau oleh semua pihak dan memiliki kredibilitas dalam implementasinya. SVLK juga 
dikembangkan di tengah tren dunia dalam perdagangan kertas yang legal. ( Dephut.go.id, 2020).

\section{Forest Stewardship Council ( FSC )}

Sertifikasi FSC memberikan kepastian bahwa produk yang digunakan berasal dari hutan yang dikelola dengan baik yang memberikan manfaat lingkungan, sosial dan ekonomi. Pemilikmaupun pengelola hutan yang ingin memperoleh sertifikat FSC harus dapat menunjukkan bahwa mereka mampu mengelola hutan secara bertanggung jawab. Sertifikasi FSC juga dapat memberikan manfaat akses pasar yang baru.Prinsip dan Kriteria FSC dikembangkan untuk mendorong praktik yang bertanggung jawab bagi pengelolaan hutan di seluruh dunia. Di banyak negara, Standar Regional maupun Standar Nasional FSC dikembangkan oleh kelompok kerja FSC. Baik standar regional dan nasional FSC akan merujuk pada FSC namun disesuaikan dengan kondisi dan konteks yang berlaku di setiap negara atau region. Sertifikasi ini memastikan bahwa praktik pengelolaan hutan yang dilakukan oleh pengelola konsesi atau pemilik lahan telah memenuhi standar pengelolaan hutan yang bertanggung jawab, yaitu keseimbangan aspek Lingkungan, Sosial, dan Ekonomi. Pengelola konsesi atau pemilik lahan yang ingin memperoleh Sertifikasi Pengelolaan Hutan dapat menghubungi lembaga sertifikasi yang terakreditasi FSC untuk mengajukan permohonan agar dilakukan penilaian. Lembaga sertifikasi akan melakukan audit lapangan untuk memastikan pengelola konsesi atau pemilik lahan telah mengelola hutan dengan baik dan memenuhi standar FSC. Jika dinilai telah memenuhi, lembaga sertifikasi akan mengeluarkan sertifikat pengelolaan hutan FSC, yang berlaku selama lima tahun dan dipantau setiap tahun untuk memastikan pengelola konsesi atau pemilik lahan selalu memenuhi standar FSC. Chain of Custody Certification atau sertifikasi lacak balak, berlaku untuk produsen, prosesor dan pedagang hasil hutan bersertifikat FSC. Sertifikasi lacak balak berfungsi untuk memastikan bahan baku kertas yang digunakan berasal dari hutan yang bersertifikat FSC di sepanjang rantai produksi bahan baku FSC tidak tercampur dengan bahan baku lain yang tidak bersertifikat. Lembaga sertifikasi melakukan verifikasi di sepanjang rantai produksi yang bersangkutan untuk memastikan bahwa produk kertas bersertifikat FSC menggunakan kertas dari hutan bersertifikat FSC, dan produknya diolah dan disimpan terpisah dari produk yang tidak bersertifikat. Bahan baku FSC hanya dapat dicampur dengan syarat dan kondisi tertentu yang diatur dalam standar FSC.(FSC.org, 2020).

\section{The Programme for the Endorsement of Forest Certification (PEFC)}

Program Persetujuan Sertifikasi Hutan, atau PEFC, adalah sebuah organisasi internasional, nonprofit dan non-pemerintah yang memberikan sertifikasi kepada pihak ketiga yang independen untuk memastikan pemanfaatan sumber daya hutan. PEFC didirikan pada tahun 1999 sebagai tanggapan terhadap persyaratan spesifik pemilik hutan sebagai organisasi payung internasional yang memberikan penilaian, dukungan, dan pengakuan independen terhadap sistem sertifikasi hutan nasional. Saat ini, PEFC adalah sistem sertifikasi hutan terbesar di dunia dengan jumlah sertifikat yang dikeluarkan.PEFC adalah label lingkungan pilihan internasional untuk pengelolaan hutan yang bertanggung jawab. Sertifikasi hutan emastikan bahwa hutan dikelola sesuai dengan kriteria lingkungan, sosial dan ekonomi. Sertifikasi Chain of Custody PEFC untuk perusahaan dalam rantai pasokan adalah mekanisme terverifikasi untuk melacak bahan bersertifikat dari hutan ke produk akhir.PEFC bekerja di seluruh rantai pasokan hutan untuk mempromosikan praktik yang baik di hutan dan untuk memastikan bahwa produk hutan pengatur waktu dan non-pengatur waktu dipenuhi dengan standar ekologi, sosial dan etika yang ditetapkan oleh PEFC. Sertifikasi PEFC memungkinkan untuk memperdagangkan produk kertas atau haisl olahan kertas tersertifikasi PEFC di pasar. Banyak kebijakan pengadaan publik dan swasta membutuhkan atau lebih memilih bahan bersertifikat PEFC (PEFC.org, 2020)

\section{METODE PENELITIAN}

Analisis data penelitian ini menggunakan Structural Equation Model (SEM) menggunakan Linear Structural Model (LISREL) versi 8.70. William dan Gavin (2004) menggunakan LISREL untuk menguji hubungan antara variabel laten dan indikator - indikator dan konstruk tersebut memiliki reliabilitas yang baik adalah jika nilai Construct Reliability $(\mathrm{CR}) \geq 0,70$ dan variance extracted values $\geq 0.50$. Data penelitian ini didasarkan pada kuesioner yang disebar di 300 responden dari 10 industri kertas di Jawa Tengah yang memiliki rencana atau telah menerapkan manajemen FSC Chain of Custody, PEFC Sustainable Forest Management dan SVLK di industri kaya dan produk berbasis kertas . Berdasarkan penelitian sebelumnya dan tujuan penulisan penelitian ini model penelitian sebagai berikut: 


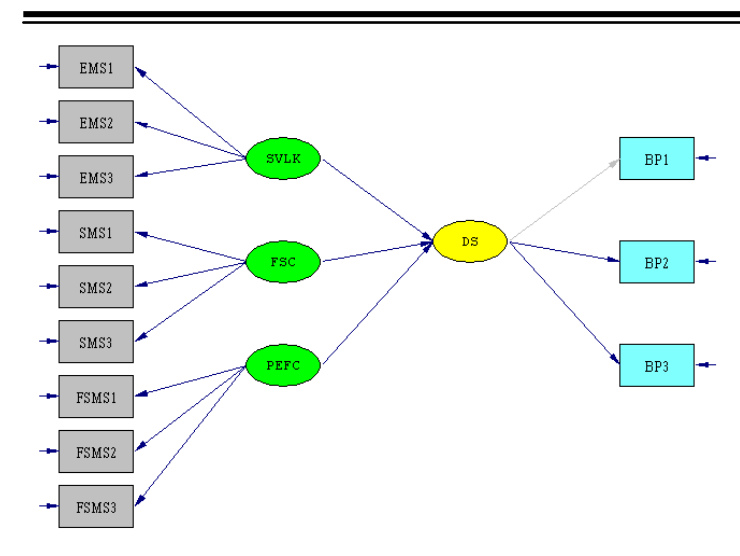

Gambar 1 Model Penelitian

Sumber : Gambar 1 berasal dari output program Lisrel (penulis, 2019)

Berdasarkan model penelitian di atas dibuat hipotesis sebagai berikut:

1. H1 : Ada hubungan yang signifikan dan positif antara penerapan SVLK (X1)dengan Daya Saing Kertas (Y).

2. H2 : Ada hubungan yang signifikan dan positif antara penerapan FSC (X2) dengan Daya Saing Industri Kertas (Y).

3. H3 : Ada hubungan yang signifikan dan positif antara penerapan PEFC (X3) dengan Daya Saing Industri Kertas (Y).

Berdasarkan hipotesis indikator - indikator variabel yang digunakan dalam penelitian ini adalah indikator utama variabel independen FSC yaitu Sistem Manajemen), Material Sourcing \& Handling , Volume Control (FSC.org, 2019). Indikator utama variabel PEFC adalah Kepemimpinan, Perencanaan \& Dukungan , Evaluasi Kinerja, Peningkatan. PEFC.org, 2019). Indikator utama SVLK adalah Persyaratan Organisasi, Penilaian Risiko, , Informasi Keluaran (ISO.org, 2019). Indikator utama variabel dependen dari Daya Saing Bisnis adalah Kepuasan Pelanggan, Peningkatan Penjualan, Penurunan Customer Complain

Penelitian ini dilakukan di beberapa industri kertas yang mengolah kertas atau menggunakan kertas sebagai bahan utama di Indonesia dengan 300 responden. Responden adalah karyawan industri kertas sebagai manajemen puncak, manajer dan staf yang memiliki rencana ataupun yang telah menerapkan FSC, PEFC dan SVLK..

Tabel 1. Profil Responden

\begin{tabular}{ccccccccc}
\multirow{2}{*}{ Wilayah } & \multicolumn{3}{c}{ Laki-laki } & \multicolumn{5}{c}{ Perempuan } \\
\cline { 2 - 8 } & Manajemen & Manajer & Staff & Manajemen & Manajer & Staff & Total \\
\hline Semarang & 8 & 13 & 12 & 7 & 8 & 6 & 54 \\
\hline Pekalongan & 9 & 21 & 15 & 5 & 12 & 14 & 76 \\
\hline Banyumas & 6 & 13 & 14 & 5 & 9 & 8 & 55 \\
\hline Kedu & 6 & 13 & 6 & 2 & 9 & 8 & 44 \\
\hline Pati & 5 & 8 & 6 & 3 & 4 & 9 & 35 \\
\hline Surakarta & 4 & 5 & 4 & 2 & 4 & 4 & 23 \\
\hline Total & $\mathbf{3 8}$ & $\mathbf{7 3}$ & $\mathbf{5 7}$ & $\mathbf{2 4}$ & $\mathbf{4 6}$ & $\mathbf{6 2}$ & $\mathbf{3 0 0}$ \\
\hline
\end{tabular}

Sumber : Tabel profil responden berasal dari ringkasan kuesioner yang dikembalikan (penulis, 2019)

\section{HASIL PENELITIAN DAN PEMBAHASAN}

Langkah pertama adalah membuat program sintaks pada software Lisrell setelah itu program dijalankan untuk mendapatkan faktor pemuatan variabel independen FSC) yaitu Sistem Manajemen Material Sourcing \& Handling Volume Control (FSC.org, 2019). Indikator utama variabel PEFC adalah Kepemimpinan Perencanaan \& Dukungan , Evaluasi Kinerja, Peningkatan . (PEFC.org, 2019). Indikator utama SVLK adalah Persyaratan Organisasi , Penilaian Risiko, Metode Pengendalian Chain of Custody, Informasi Keluaran (ISO.org, 2019). Indikator utama variabel dependen dari Daya Saing Bisnis adalah Kepuasan Pelanggan Peningkatan Penjualan Produktivitas Analisis data dilakukan oleh Structural Equation

Model (SEM) menggunakan Linear Structural Model (LISREL) versi 8.70 dari Joreskog dan Sorbom (2008), dan hasilnya ada pada gambar berikut :

\begin{tabular}{|rccc|}
\hline OBSERVED VARIABLES & X11 & X12 \\
X13 & X14 & X21 & X22 \\
X23 & X24 & X31 & X32 \\
X33 & X34 & Y1 & Y2 \\
Y3 & Y4 & & \\
RAW DATA FROM FILE & DATADIAN.PSF \\
SAMPLE SIZE = 417 &
\end{tabular}

Gambar 2. Program Sintaks pada Software Lisrell

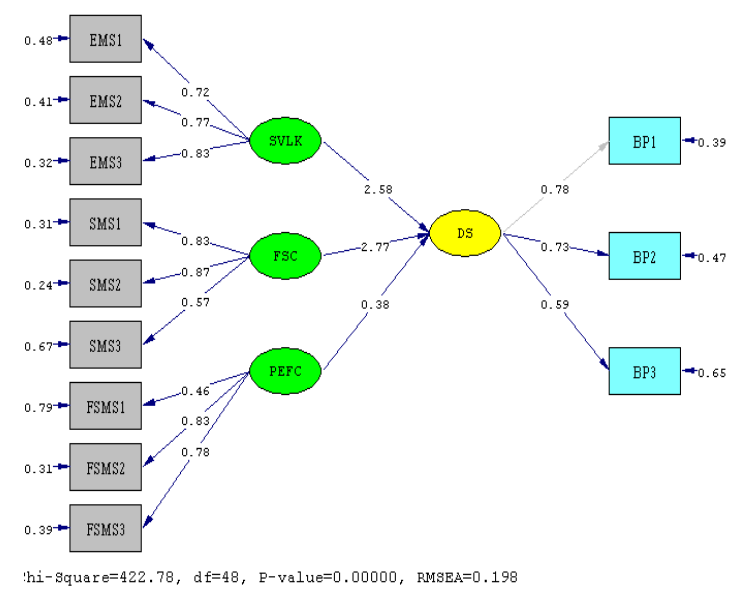

Gambar 3 Nilai Loading Factor Indikator

Sumber : Angka tersebut berasal dari output pemrosesan program Lisrell (penulis, 2019) 
https://ejurnal.stimi-bjm.ac.id/index.php/JRIMK

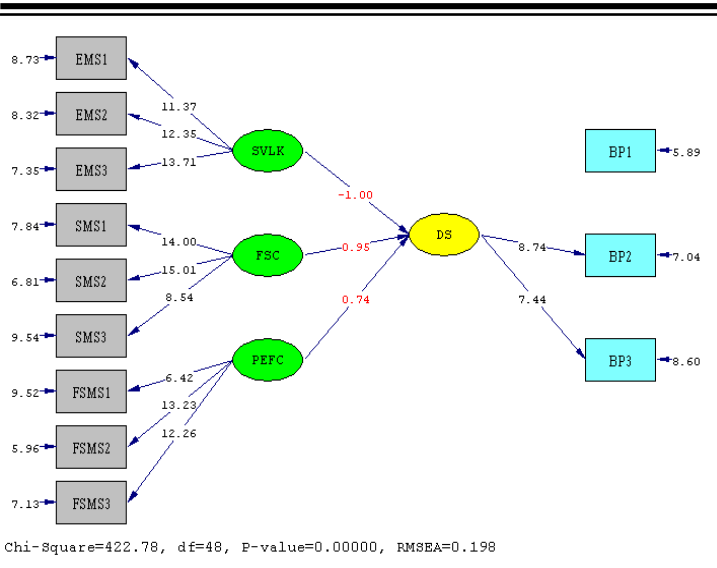

Gambar 4. Indikator t-Value

Sumber : Angka tersebut berasal dari output pemrosesan program Lisrell (penulis, 2019)

Berdasarkan gambar 3 dan gambar 4 saya menyimpulkan bahwa tidak ada varians error nilai negatif, dan nilai loading faktor FSC, PEFC dan SVLK di atas 0,5 $(>0,5)$ dan nilai t dari loading faktor lebih besar dari 1,96 (> 1,96). Ini adalah semua indikator valid dan signifikan.

\begin{tabular}{|c|c|c|c|c|}
\hline Variabel & Indikators & $\begin{array}{c}\text { Pemuatan } \\
\text { Faktor }\end{array}$ & $\begin{array}{r}T- \\
\text { Value }\end{array}$ & Keterangan \\
\hline \multirow{3}{*}{$\mathrm{FSC}(\mathrm{X} 1)$} & Sistem Manajemen & 0.72 & 11.37 & Valid \& Sig \\
\hline & Sumber\&Penanganan Material & 0.77 & 12.55 & Valid \& Sig \\
\hline & Kontrol Volume & 0.83 & 13.71 & Valid \& Sig \\
\hline \multirow{3}{*}{ PEFC (X2) } & Kepemimpinan & 0.96 & 14.00 & Valid \& Sig \\
\hline & Perencanaan \& Dukungan & 0.83 & 15.00 & Valid \& Sig \\
\hline & Evaluasi Kinerja & 0.78 & 8.54 & Valid \& Sig \\
\hline \multirow{3}{*}{$\begin{array}{l}\text { SVLK } \\
\text { (X3) }\end{array}$} & Persyaratan Organisasi & 0.47 & 6.42 & Valid \& Sig \\
\hline & Resiko Tugas & 0.83 & 13.23 & Valid \& Sig \\
\hline & Informasi Luar & 0.76 & 12.26 & Valid \& Sig \\
\hline \multirow{3}{*}{$\begin{array}{l}\text { Daya Saing Bisnis } \\
\text { (Y) }\end{array}$} & Kepuasan Pelanggan & 0.78 & 5.68 & Valid \& Sig \\
\hline & Peningkatan Penjualan & 0.77 & 8.74 & Valid \& Sig \\
\hline & Produktifitas & 0.53 & 7.44 & Valid \& Sig \\
\hline
\end{tabular}

Catatan:Angka tersebut berasal dari output pemrosesan program Lisrell (penulis, 2019)

Semua area memuat faktor yang valid dan signifikan. Variabel independen FSC adalah Sistem Manajemen, Pengadaan \& Penanganan Material , Kontrol Volume (FSC.org, 2019). Indikator utama variabel PEFC adalah Kepemimpinan, Perencanaan \& Dukungan, Evaluasi Kinerja, Peningkatan. (PEFC.org, 2019). Indikator utama SVLK adalah Persyaratan Organisasi, Penilaian Risiko, Metode Pengendalian Chain of Custody, Informasi Keluaran (ISO.org, 2019).

Indikator utama variabel dependen dari Daya Saing Bisnis adalah Kepuasan Pelanggan, Peningkatan Penjualan, Produktivitas. Hasil ini dapat disimpulkan bahwa Chain of Custody FSC, PEFC Sustainable Forest Management dan SVLKChain of custody kertas dan produk berbasis kertas valid dan signifikan. Hasil validitas juga diperkuat oleh nilai Chi-Square (r) yang menghasilkan nilai 422.78. Langkah selanjutnya adalah menghitung nilai Construct Reliability (CR) dan Value of variance entrance (VR) pada tabel 4.

Tabel 4 Hasil Analisis Orde Kedua

\begin{tabular}{|c|c|c|c|c|c|}
\hline Indikator & $\begin{array}{c}\text { Loading } \\
\text { Faktor }\end{array}$ & $\begin{array}{l}\text { Loading } \\
\text { Faktor2 }\end{array}$ & $\begin{array}{c}\text { 1-Loading } \\
\text { Faktor2 }\end{array}$ & $C R$ & $\mathrm{VE}$ \\
\hline Sistem Manajemen & 0.72 & 0.43 & 0.63 & \multirow{12}{*}{0.89} & \multirow{12}{*}{0.75} \\
\hline Sumber\&Penanganan Material & 0.77 & 0.34 & 0.63 & & \\
\hline Kontrol Volume & 0.83 & 0.44 & 0.64 & & \\
\hline Kepemimpinan & 0.96 & 0.94 & 0.43 & & \\
\hline Perencanaan \& Dukungan & 0.83 & 0.63 & 0.83 & & \\
\hline Evaluasi Kinerja & 0.78 & 0.56 & 0.77 & & \\
\hline Persyaratan Organisasi & 0.47 & 0.34 & 0.13 & & \\
\hline Resiko Tugas & 0.83 & 0.64 & 0.72 & & \\
\hline Informasi Luar & 0.76 & 0.46 & 0.58 & & \\
\hline Kepuasan Pelanggan & 0.78 & 0.56 & 0.56 & & \\
\hline Peningkatan Penjualan & 0.77 & 0.57 & 0.49 & & \\
\hline Produktifitas & 0.53 & 0.34 & 0.71 & & \\
\hline
\end{tabular}

Catatan : Tabel berasal dari output pemrosesan program Lisrell (penulis, 2019).

Berdasarkan perhitungan rumus $\mathrm{CR}$ konstruksi reliabilitas diperoleh hasil dan indikator adalah $0,89(\mathrm{CR}) \geq 0,70$ dan $0,75(\mathrm{VE}) \geq 0,50$ dan disimpulkan bahwa semua indikator memiliki reliabilitas yang baik dan konstruk nilai memiliki reliabilitas yang baik. Oleh karena itu, berdasarkan hasil analisis uji reliabilitas dapat disimpulkan bahwa reliabilitas seluruh indikator merupakan indikator yang baik dan dapat disimpulkan bahwa penelitian memenuhi persyaratan. Langkah selanjutnya adalah melaksanakan Analisis Goodness of Fit ( GOF), data GOF diperoleh dari hasil eksekusi software.

\section{Analisis Goodness Of Fit (GOF)}

Uji kebaikan dan kesesuaian model pada keseluruhan model fit tentang analisis nilai GOF statistik yang dihasilkan oleh program lisrel, untuk relevansi model (model fit) yang cukup baik dan untuk modelnya sesuai dengan kriteria seperti yang ditunjukkan pada Tabel 5.

Tabel 5 Goodness Of Fit

\begin{tabular}{lccc}
\hline \multicolumn{1}{c}{ Indeks Fit } & Nilai & StandarNilai & Keterangan \\
\hline Chi-Square & 422.78 & $>0.5$ & Fit \\
\hline $\begin{array}{l}\text { Root Mean Square Error of Approximation } \\
\text { (RMSEA) }\end{array}$ & 0.04 & $<0.08$ & Fit \\
\hline Index of Normed Fit(NFI) & 0.96 & $>0.90$ & Fit \\
\hline Index of Non-NormedFit(NNFI) & 0.92 & $>0.90$ & Fit \\
\hline Index of ComparativeFit(CFI) & 0.91 & $>0.90$ & Fit \\
\hline Index of Incremental Fit(IFI) & 0.93 & $>0.90$ & Fit \\
\hline Index of RelativeFit(RFI) & 0.92 & $>0.90$ & Fit \\
\hline Goodness of Fit Index (GFI) & 0.91 & $>0.90$ & Fit \\
\hline
\end{tabular}

Catatan : Tabel berasal dari output pemrosesan program Lisrell (penulis, 2019)

Berdasarkan hasil analisis dapat disimpulkan bahwa semua indikator sudah fit dan dapat disimpulkan bahwa keseluruhan model masih 
cocok. Model persamaan (Structural Equations) linier dari 8.70 perangkat lunak LISREL diperoleh sebagai berikut:

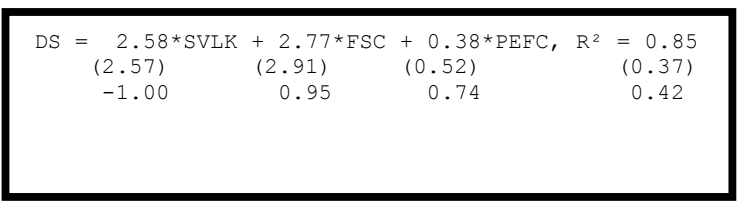

Gambar 4 Persamaan Struktural

Catatan : Gambar 5 Output pemrosesan program Lisrell (penulis, 2019)

Berdasarkan hasil dari semua analisis di atas, dapat dilihat bahwa FSC pengelolaan hutan, PEFC dan SVLK berpengaruh positif dan signifikan terhadap kinerja industri kertas . Dengan nilai $\mathrm{t}$ sama dengan 2.57. Model goodness of fit diproduksi cukup baik dengan nilai chi-square 422.78. Nilai R Square 0,85 berarti Implementasi FSC, PEFC dan SVLKtelah mempengaruhi kinerja industri kertas sebesar $85 \%$ sementara faktorfaktor lain mempengaruhi $15 \%$. Jadi dapat disimpulkan dan diperoleh persamaan regresi berikut (daya saing industri kertas) $=\mathrm{DS}=$ $2.58 *$ SVLK $+2.77 *$ FSC $+0.38 *$ PEFC

Berdasarkan hasil analisa data diperoleh hasil ada hubungan yang signifikan dan positif antara penerapan FSC dengan Kinerja Industri Kertas Ada hubungan yang signifikan dan positif antara penerapan PEFC dengan Kinerja Industri Kertas Ada hubungan yang signifikan dan positif antara penerapan SVLK dengan daya saing industri kertas.

\section{PENUTUP}

\section{Kesimpulan}

Berdasarkan analisis hasil penelitian dapat disimpulkan bahwa penerapan FSC Chain of Custody, PEFC Sustainable Forest Management dan SVLK dan produk berbasis kertas memiliki dampak positif dan signifikan terhadap kinerja industri kertas seperti meningkatkan indeks kepuasan pelanggan, meningkatkan penjualan dan meningkatkan produktivitas sehingga akan meningkatkan laba perusahaan. Objek penelitian tidak hanya di Indonesia tetapi juga dapat diperluas ke negara lain. Hasil penelitian ini implementasi FSC Chain of Custody, PEFC Sustainable Forest Management dan SVLKChain of custody sistem manajemen produk berbasis kertas dan memiliki pengaruh pada daya saingperusahaan sehingga perusahaan yang belum mengimplementasikannya dapat direkomendasika nuntuk segera menerapkan FSC Chain of Custody, PEFC Sustainable Forest Management dan SVLKChain of custody kertas dan produk berbasis kertas, studi ini memperkuat hasil penelitian sebelumnya. Purwanto dkk. (2019) menyatakan bahwa pengelolaan hutan berpengaruh signifikan dan positif terhadap kinerja bisnis. Santoso et al. (2019) menyatakan bahwa FSC pengelolaan hutan berpengaruh signifikan dan positif terhadap kinerja bisnis.

Studi ini berkontribusi pada penelitian tentang manfaat FSC Chain of Custody, PEFC Sustainable Forest Management dan SVLKChain of custody sertifikasi produk kertas dan produk berbahan dasar kertas , Keterbatasan penelitian ini adalah tidak membahas tentang indikator kinerja keuangan, jadi dalam penelitian masa depan, indikator kinerja keuangan dapat diukur selama periode waktu tertentu. Selain itu, perbandingan kinerja keuangan FSC Chain of Custody, PEFC Sustainable Forest Management dan SVLKChain of custody kertas dan produk kertas pemegang Sertifikat dapat dibuat. FSC Chain of Custody, PEFC Sustainable Forest Management dan SVLKChain of custody kertas dan produk-produk berbahan dasar kertas berlaku untuk semua organisasi yang memperdagangkan, memproses atau memproduksi kertas dan produk hutan. Manfaat penerapan FSC Chain of Custody, PEFC Sustainable Forest Management dan SVLKChain of custody kertas dan sertifikasi produk berbahan dasar kertas yaitu mempertahankan pelanggan yang merupakan manfaat utama sertifikasi, meningkatkan pelanggan baru, meningkatkan ekspor, meningkatkan citra perusahaan, meningkatkan laba, komitmen terhadap tanggung jawab lingkungan yang meningkatkan citra perusahaan, mempromosikan, penggunaan sumber daya hutan secara berkelanjutan, meningkatkan komunikasi dengan pelanggan, mencegah pembalakan liar, dan meningkatkan efisiensi pengelolaan.

Hasil penelitian menunjukkan bahwa FSC Chain of Custody, PEFC Sustainable Forest Management dan SVLK kertas dan sertifikasi produk berbahan dasar kertas merupakan prasyarat untuk kinerja dan daya saing bagi perusahaan. Salah satu manfaat dari penelitian ini adalah untuk meyakinkan pemilik kertas dan perusahaan pengolahan untuk mendapatkan FSC Chain of Custody, PEFC Sustainable Forest Management dan SVLK industri produk-produk berbahan dasar kertas bersertifikat karena manfaat dari penerapannya telah diuji dan juga sebagai bentuk kepatuhan terhadap hukum dan peraturan sehingga dapat meningkatkan citra baik perusahaan.

Penelitian ini memiliki beberapa keterbatasan, sampel tidak mewakili populasi target, jumlah sampel yang tidak banyak karena waktu dan biaya yang terbatas, objek penelitian ini hanya perusahaan industri kertas di Jawa Tengah walaupun lebih banyak perusahaan lain yang telah menerapkannya di negara lain. Keterbatasan waktu penelitian dan jumlah responden yang hanya 300 responden belum meyakinkan untuk 
menggeneralisasi hasil penelitian. Sofware yang digunakan untuk analisis data adalah Lisrel dan banyak orang belum mengenal software ini. Studi ini tidak membahas beberapa indikator keuangan sehingga tidak dapat diketahui manfaat finansial nyata dari penerapan FSC Chain of Custody, PEFC Sustainable Forest Management dan SVLKChain of custody kertas dan produk berbahan dasar kertas , pada penelitian berikutnya membahas tentang indikator keuangan dengan membandingkan kondisi keuangan FSC Chain of Custody, PEFC Sustainable Forest Management dan SVLKChain of custody kertas dan produk berbahan dasar kertas perusahaan bersertifikat dan tidak bersertifikat. Penelitian ini hanya meneliti industri kertas meskipun banyak perusahaan yang menerapkan FSC Chain of Custody, PEFC Sustainable Forest Management dan SVLKChain of custody kertas dan produk-produk berbahan dasar kertas seperti distributor kertas, pabrik kertas dan lain-lain. Untuk penelitian lebih lanjut, disarankan untuk memeriksa perusahaan di seluruh rantai mulai dari kertas hingga pengguna akhir.

\section{Ucapan Terima Kasih}

Ucapan terimakasih kami sampaikan kepada kepada semua pihak yang telah membantu dalam pelaksanaan riset ini yaitu Bapak Innocentius Bernarto yang telah membimbing kami, seluruh para responden yang telah meluangkan waktu untuk mengisi kuesioner dan seluruh teman-teman DRM EDU Universitas Pelita Harapan yang telah membantu mengolah data kuesioner.

\section{DAFTAR PUSTAKA}

Baccini, A., Goetz, S.J., Walker, W.S. (2012). Estimated carbon dioxide emissions from tropical deforestation improved by carbondensity maps. Nat Clim Change. https://doi.org/10.1038/NCLIMATE1354x

Brown, H.C, Lassoie, J.P., (2010). Institutional choice and local legitimacy in communitybased forest management: lessons from Cameroon. Environ Conserv 37, 261-269.

Brown, M.I.(2013). Redeeming REDD: Policies, Incentives and Social Feasibility For Avoided Deforestation. Earthscan, London.

Fujita, K. and Shaw, R. (2010), "Chapter 7 Forest management as an adaptation option in mountain areas FSC.org.(2019), FSC Chain of Custody , accessed 26 December 2019
Purwanto, A., Sihite, B.O.,Yanthy, E., Hutagalung, L. (2019). Influence of Forest Management System FSC, PEFC and ISO 38200:2018 Toward Business Performance at Wood and Paper Industries in Sumatera Indonesia, Saudi Journal of Business and Management Studies, 4(12). $\quad$ 892-897.

DOI: http://10.36348/sjbms.2019.v04i12.005

Purwanto, A . (2019). Effect of Implementation ISO 38200:2018 Chain of Wood Products Custody Toward Wood Industries Business Competitiveness In Pati Central Java Indonesia, International Journal of Scientific Research in Science and Technology(IJSRST), 6 (6).261-268. doi : https://doi.org/10.32628/IJSRST196649

Santoso, P, Purwanto, A., \& Asbari, M.(2019). Influence of Implementation Chain of Custody Forest Management System FSC-STD-40-004 V3-0 to Business Performance of Paper Industriesia in Banten Indonesia, International Journal of Management and Humanities (IJMH), 4(4), 32-36. DOI: https://doi.org/10.35940/ijmh.C0442D0482.12 $\underline{4419}$

Purwanto, A., Sihite, B.O.,Yanthy, E., Hutagalung, L. (2019). Influence of Forest Management System FSC, PEFC and ISO 38200:2018 Toward Business Performance at Wood and Paper Industries in Sumatera Indonesia, Saudi Journal of Business and Management Studies, 4(12). 892-897. DOI: http://10.36348/sjbms.2019.v04i12.005

Purwanto, A., Asbari, M., \& Santoso, P.(2019). Can ISO 38200:2018 Wood and Wood Based Product Chain of Custody Increase Businesss Competitiveness of Wood Industries in West Java ?. Jurnal Hutan dan Masyarakat. 8 (2).113-125. http://dx.doi.org/10.24259/jhm.v11i2.8358

Harris, N.L., Brown, S., Hagen, S.C., Saatchi, S.S., Petrova, S., (2012). Baseline map of carbon emissions from deforestation in tropical regions. Science 336, 1573-1576.

Hirschberger, Peter (2005): The Effects of FSCcertification in Latvia: an analysis of CARs. WWF Forest Programme.29 p. http://www.panda.org/downloads/forests/fscan alysislatvia.pdf (as of June 2008)

ISO.org,(2019), SVLKChain of custody of wood and wood-based products,accessed 26 December 2019 
Lee, D., Llopis, P., Waterworth, R., Roberts, G., Pearson, T.(2018). Approaches to REDD+Nesting : Lessons Learned from Country Experiences. World Bank, Washington, DC.

Lewis, R.A., Davis, S.R.(2015). Forest certification, institutional capacity, and learning: an analysis of the impacts of the Malaysian Timber Certification Scheme. For. Pol. Econ. 52, 18-26. Maletz, O., Tysiachniouk.

Newsom, Deanna and Hewitt, Daphne (2005): The Global Impacts of SmartWood Certification. Final Report ofthe TREES Program for the Rainforest Alliance.

http://www.rainforestalliance.org/programs/for estry/perspectives/documents/sw_impacts.pdf (as of June 2008)

Pinto, L.F.G., McDermott, C.L., (2013). Equity and forest certification - a case study in Brazil. For. Pol. Econ. 30, 23-29.

PEFC.org, (2019), PEFC Sustainable Forest Management, accessed 26 December 2019

Renström, Margareta and Rainey, Margaret (WWF Sweden) (2001): Social issues and the Forestry StewardshipCouncil. Sustainable Development International 4,137-139. http://www.p2pays.org/ref/40/39769.pdf (as ofJune 2008)160 Ros-Tonen, Mirjam

Santoso, P, Purwanto, A., \& Asbari, M.(2019). Influence of Implementation Chain of Custody Forest Management System FSC-STD-40-004 V3-0 to Business Performance of Paper Industriesis in Banten Indonesia, International Journal of Management and Humanities (IJMH), $\quad 4(4), \quad 32-36 . \quad$ DOI: https://doi.org/10.35940/ijmh.C0442D0482.12 $\underline{4419}$

Sunderlin, W.D., Angelsen, A., Belcher, B., Burgers, P., Nasi, R., et al., (2005). Livelihoods, forests, and conservation in developing countries: an overview. World Dev. 33, 1383-1402.

Sunderlin, W.D., Hatcher, J., Liddle, M., (2008). From Exclusion to Ownership? Challengesand Opportunities

Sloan, S., Sayer, J.A., (2015). Forest Resources Assessment of 2015 shows positive global trends but forest loss and degradation persist in poor tropical countries. For. Ecol. Manage. 352, 134-145.
Sills, E.O., Atmadja, S.S., de Sassi, C., Duchelle, A.E., Kweka, D.L., Resosudarmo, I.A.P.,Sunderlin, W.D. (Eds.), (2014). REDD+ On the Ground: a Case Book of Sub-national Initiatives Across the Globe. CIFOR, Bogor, Indonesia

Tysiachniouk, Maria (2005): Forest Certification in Russia. (Center for Independent Social Research St. Petersburg,Russia); Paper presented at Yale Forest Certification Symposium. published by Yale school of forestry \& environmentalstudies. http://www.yale.edu/forestcertification/sympo sium/pdfs/Book\%20Chapters/12\%20Russia.pd $\mathrm{f}$ (as of June 2008)

Williams, Gavin (2004) "Structural Equation Modeling Methods In Strategy Research: Application and Issue" Research Methodology in Strategy and Management (Research Methodology in Strategy and Management, Vol. 1), Emerald Group Publishing Limited, Bingley, pp. 303-346. https://doi.org/10.1016/S1479-8387(04)01111$\underline{7}$

\section{Profil penulis}

1. Agus Purwanto, Universitas Pelita Harapan, Jl. MH. Thamrin Boulevard 1100, Kelapa Dua, Kec. Karawaci, Kota Tangerang, Banten 15811

Email: agozpor@gmail.com

2. Mirza Prameswari, Universitas Pelita Harapan, Jl. MH. Thamrin Boulevard 1100, Kelapa Dua, Kec. Karawaci, Kota Tangerang, Banten 15811

Email: mirza.poppy96@gmail.com

3. Fredson Kotamena, Universitas Pelita Harapan, Jl. MH. Thamrin Boulevard 1100, Kelapa Dua, Kec. Karawaci, Kota Tangerang, Banten 15811

Email: fredson_k@yahoo.com

4. Masduki Asbari, Universitas Pelita Harapan, Jl. MH. Thamrin Boulevard 1100, Kelapa Dua, Kec. Karawaci, Kota Tangerang, Banten 15811

Email: kangmasduki.ssi@gmail.com

5. Priyono Budi Santoso, Universitas Pelita Harapan, Jl. MH. Thamrin Boulevard 1100, Kelapa Dua, Kec. Karawaci, Kota Tangerang, Banten 15811

Email: priyono@gt-tires.com

6. Mohamad Ramdan, Universitas Pelita Harapan, Jl. MH. Thamrin Boulevard 1100, Kelapa Dua, Kec. Karawaci, Kota Tangerang, Banten 15811

Email: mohamad.ramdan@gmail.com 
7. Andi Sulistiadi, Universitas Pelita Harapan, Jl. MH. Thamrin Boulevard 1100, Kelapa Dua, Kec. Karawaci, Kota Tangerang, Banten 15811

Email: andisulistiadi.edu@gmail.com

8. Laksmi Mayesti Wijayanti, Universitas Pelita Harapan, Jl. MH. Thamrin Boulevard 1100, Kelapa Dua, Kec. Karawaci, Kota Tangerang, Banten 15811

Email: miss_lakmsi@yahoo.com

9. Choi Chi Hyun, Universitas Pelita Harapan, Jl. MH. Thamrin Boulevard 1100, Kelapa Dua, Kec. Karawaci, Kota Tangerang, Banten 15811

Email: bae7042@daum.net

10. Otto Berman Sihite, Universitas Pelita Harapan, Jl. MH. Thamrin Boulevard 1100, Kelapa Dua, Kec. Karawaci, Kota Tangerang, Banten 15811

Email: ottosihite996@gmail.com

11. Rudy Pramono, Universitas Pelita Harapan, Jl. MH. Thamrin Boulevard 1100, Kelapa Dua, Kec. Karawaci, Kota Tangerang, Banten 15811

Email: rudy.pramono@uph.edu 